The impact of country culture on the adoption of new forms of work organization

Raffaella Cagliano, School of Management, Politecnico di Milano

Federico Caniato, School of Management, Politecnico di Milano

Ruggero Golini, Department of Economics and Technology Management, Università di Bergamo

Annachiara Longoni, School of Management, Politecnico di Milano

Evelyn Micelotta, Department of Strategic Management and Organization, School of Business University of Alberta

Article published in International Journal of Operations and Production Management

Please cite as: Cagliano, R., Caniato, F., Golini, R., Longoni, A., \& Micelotta, E. (2011). The impact of country culture on the adoption of new forms of work organization. International Journal of Operations \& Production Management, 31(3), 297-323.

Doi: https://doi.org/10.1108/01443571111111937 


\section{The impact of country culture on the adoption of new forms of work organization}

\section{Abstract}

Purpose

This paper aims at understanding the relationship between the adoption of New Forms of Work Organizations (NFWO) and measures of country impact, in terms of national culture and economic development.

\section{Methodology}

The adoption of NFWO practices is measured through data from the fourth edition of the International Manufacturing Strategy Survey, while Hofstede’s (2005) measures are adopted for national culture, and Gross National Income (GNI) per capita is used as an economic development variable. Multivariate linear regression is applied to investigate relationships, using company size as a control variable. A cluster analysis is utilized to identify groups of countries with similar cultural characteristics and to highlight different patterns of adoption of NFWO practices.

\section{Findings}

We show that it is possible to explain different patterns in the adoption of NFWO practices when considering company size and cultural variables. GNI is instead only significant for some practices and does not always positively influence the adoption of NFWO. On the other hand, cultural variables are linked to all the practices, but there is no dominant dimension to explain higher or lower NFWO adoption.

\section{Research limitations/implications}

Results are limited because only Hofstede's cultural variables are used and manufacturing performance is not considered. Therefore, it is not possible to discriminate between more or less successful NFWO variations.

\section{Practical implications}

This research provides managers with insights on how to take into account cultural variables when transferring organizational models to different countries.

Value

This paper contributes to previous studies showing the importance of including several contextual variables, country impact in particular, in the study of operations management.

Keywords: New Forms of Work Organization (NFWO), national culture, country variable, IMSS 


\section{Introduction}

In western economies, several forces have driven manufacturing companies to adopt new models and practices to organize their work systems, often referred to as New Forms of Work Organization (NFWO) (e.g., Smith, 1997; European Commission, 2002) and High-Performance Work Systems (HPWS) (e.g., Appelbaum et al., 2000; Shih et al., 2006), among others (Way, 2002; Hartog and Verbrurg, 2004), and include practices such as team work, multi-skilling, delegation, job enrichment, job enlargement, training, and involvement. The importance of these changes is widely recognized by scholars, managers, and policy makers (Spina et al., 1996; Ichniowski and Shaw, 1999; Ahmad and Schroeder, 2003; Budhwar and Sparrow, 2002; European Commission, 2002; Cagliano et al., 2005).

Since the early studies of this paradigmatic shift, the problem of transferability of these models in different countries has been central to the academic and practitioner debates. Many studies concluded that transferability is possible - and this is widely confirmed by the current practices of many companies - but with due consideration of the need to select and adapt the appropriate aspects or practices of the theoretical model (Womack et al., 1990; Hines et al. 2004; Schonberger, 1982).

Despite the fact that several studies have analyzed the role of the country variable in the adoption of advanced organizational forms, these more frequently focused on countries' macro-economic factors, such as GDP, rate of employment, labor market characteristics, and job regulation, among others (e.g., Schuler et al., 1993; Spina et al., 1996; Ettlie, 1997). Also, many studies have mentioned national culture as an important explanation of differences in the adoption of new organizational models (e.g., Schneider, 1989; Harrison et al., 1994; Winch et al., 1997; Sethi and Elango 1999 and Budhwar and Sparrow, 2002). However, there is a lack of quantitative studies that measure in detail the extent of such influence. In addition, there is also a need to better understand the separate and relative roles of two important dimensions characterizing the national setting, that is, the level of economic development and the characteristics of the national culture.

This paper contributes to this debate by exploring, on a wide empirical basis and across multiple countries, the relationship between the adoption of NFWO, the level of economic development, and the measures of national culture.

The paper is organized as follows. First, we review the literature on organizational models in production, highlighting the main features of NFWO. We then examine the existing studies on the influence of the country variable on the adoption of advanced organizational models, and we introduce the dimensions of national culture provided by Hofstede $(1983,1991)$. Second, we provide details about the specific research questions of the paper, the methodology used for the research and the measures of the relevant variables. Finally, we present and discuss the results of the analyses. Limitations and suggestions for further research are addressed in the conclusions of the paper.

\section{Literature review}




\section{New forms of work organization}

In the last decades, significant changes took place in the way work is organized within manufacturing companies.

Emerging organizational models, such as Just-in-Time (JIT), Lean Production, Total Quality Management (TQM), Continuous Improvement or Toyota Production System (see e.g., Shingo, 1981; Schonberger, 1982 and 1986; Monden, 1983; Womack et al., 1990), and also other experiences outside Japan, such as Flexible Specialization (Piore and Sabel, 1984) or so-called “Volvoism” (Berggren, 1994; Clarke, 2005), proved to have a higher capability of supporting flexibility and speed, often maintaining high performance levels in terms of productivity and quality. These approaches were developed and evolved in the fields of operations and production management, but also entailed a completely new organizational approach. For example, MacDuffie (1995) refers to a new “organizational logic,” proposing a bundle of inter-related, internally consistent manufacturing practices linked to a bundle of human resource management (HRM) practices. Also, Lean Enterprise is seen as a new organizational model in which the human factor plays an important role in ensuring lean process management is successful (Voss and Robinson, 1987; Shah and Ward, 2003; Womack at al., 1990; Karlsson, 1996). In a recent study, Radnor and Boaden (2004) assert that the change concerning Lean adoption generates potential effects on all aspects of the organization.

Taking a considerably different perspective, the Organization Theory and HRM literature proposes similar conceptualizations of the changes in organizational models: HPWS, developed in the US and more focused on HRM issues (e.g., Appelbaum et al., 2000; Shih et al., 2006) and NFWO, defined in Europe for the purpose of integrating organizational design and HRM practices (e.g., Smith, 1997; European Commission, 2002). Most scholars include the following organizational and HRM practices: job enlargement and job rotation (Landsbergis et al., 1996; de Treville and Antonakis, 2006; Ichniowski et al., 1997; Smith, 1997; Way, 2002); employee development and training (Bullinger, 1997; Guest, 1997; Ichniowski et al., 1997; Appelbaum et al., 2000; Way, 2002; Hult et al., 2003; Wright et al., 2003; Hartog and Verburg, 2004); participation and empowerment (Hartog and Verburg, 2004) through development of problem solving capabilities (Landsbergis et al., 1996) and reduction of hierarchical levels (Gunn, 1987; Hayes et al., 1988; Åhlström and Karlsson, 2000), teamwork and multifunctional teams (Karlsson and Åhlström, 1995; Delaney and Huselid,1996; Guest, 1997; Ichniowski et al., 1997; Smith, 1997; Way, 2002; Hartog and Verburg, 2004); and incentives compensation, especially at the team level (Ichniowski et al., 1997; Appelbaum et al., 2000; Way, 2002; Wright et al., 2003).

\section{National influence in the adoption of management practices}

Most of the manufacturing paradigms described in the previous section were initially introduced in the automotive industry in Japan, but have subsequently spread across different countries and industrial sectors. The very first advocates of the lean production model explicitly put forward the thesis of "transference," i.e., 
the possibility for non-automotive and non-Japanese plants to adopt, with the proper adaptation and selection, the general principles and practices of the new paradigm (e.g., Womack et al., 1990; Hines et al. 2004).

Subsequently, a number of studies explored the impact of the country variable on the adoption of the new manufacturing paradigm (e.g., Spina et al., 1996; Voss and Blackmon, 1996; Brodner and Latniak, 2002; European Commission, 2002; Gonzalez-Benito, 2005; Bartezzaghi and Cagliano, 2007). These international comparisons helped to identify whether such practices are dependent on a geographical idiosyncrasy or are applicable in national and cultural settings other than the original.

The literature on the role of the country factor in adopting new HRM practices is also widespread. These studies generally explore the country variable within a more general framework of contingent variables, and conclude that the adoption of innovative HRM practices is primarily determined by different regional and national settings (e.g., Ichniowski and Shaw, 1999; Ahmad and Schroeder, 2003; Budhwar and Sparrow, 2002). These studies also assert that the country variable is multi-faceted (Sethi and Elango, 1999; Zaheer and Zaheer, 1997; Makino et al., 2004). In their research on the causes of different performance levels of affiliates of multinational organizations, Makino et al. (2004) propose a wide classification of the different aspects concerning national influence: economic aspects, political and social aspects, institutional differences, and cultural aspects.

In particular, a wide range of studies in management literature explore how, or imply that, national culture is critical to managerial practices or organizational strategic adaptation (Metters, 2008). The relevance of the national culture in studying differences in manufacturing practices is confirmed also by studies, such as that of Burgess (1995), who addresses worldwide manufacturing competitiveness, Pagell et al. (2005)'s research on similar manufacturing plants in the same industry located in different countries, and Metters' (2008) research on outsourcing services. In addition, in the HRM literature a number of studies show the importance of understanding the main determinants of policies and practices in different regional and national settings that are linked to the national culture (Budhwar and Sparrow, 2002). The study of the European Commission (2002) confirmed this view in relation to NFWO.

\section{Hofstede's cultural dimensions}

When addressing national culture issues, Hofstede $(1980,1991)$ is usually one of the most cited scholars. He developed a quantitative model to measure similarities and differences between national cultures, based on four dimensions.

Individualism describes the relationship between the individual and the collective. A given society's norm for individualism versus collectivism will strongly affect the nature of the relationship between people and the organization to which they belong. 
Masculinity is related to the evidence that dissimilar societies cope differently with gender roles. In countries with a lower masculinity index (higher levels of femininity), life satisfaction of workers tends to take precedence over job success.

Power distance reflects inequality in power depending on prestige, influence, wealth, and status. High power distance societies tend to use more coercive and referent power, whereas low power distance societies use more legitimate power.

Uncertainty avoidance measures the extent to which countries deem the pursuit of certainty important. Cultures with high uncertainty avoidance reveal a preference for long-term predictability of rules, work arrangements, and relationships, as well as an avoidance of risk-taking.

The country scores provided by Hofstede have been extensively adopted in studies on national culture to show the impacts on "management practices" in terms of strategy (Schneider and Demeyer, 1991), style of leadership (Dorfman and Howell, 1988), organizational practices (Newman and Nolle, 1996, Bates et al., 1995; Eylon and Au, 1999; Harrison et al., 1994), HRM (Luthans et al., 1993), and new product development (Nakata and Sivakumar, 1996). Examples of studies using Hofstede's model to explain differences in manufacturing practices are: Bates et al. 1995; Burgess, 1995; Pagell et al., 2005; Vecchi and Brennan, 2009.

Other researchers have addressed the study of country culture from different perspectives, and have proposed more complex models for measuring culture (e.g., Hair et al., 1963; Laurent, 1986). Recently, the GLOBE project has begun citing results of a wide-scale study by more than 150 researchers collecting information on more than 18,000 middle managers in 62 countries (Javidan and House, 2001). The nine critical cultural dimensions considered, partially overlapping Hofstede's, are: performance orientation, future orientation, assertiveness, uncertainty avoidance, power distance, collectivism, family collectivism, gender differentiation, and humane orientation. Regardless of the operationalization, all these research efforts reach similar conclusions. Specifically, culture is multi-dimensional and can explain some of the variance in managerial behaviors and adoption of managerial practices (Pagell et al., 2005).

In summary, many scholars agree in identifying the work of Hofstede (1980) as the major contribution to understanding national business cultures (e.g., Smith, 1992; Harrison et al., 1994; Burgess, 1995; Newman and Nollen, 1996; Winch et al., 1997; Trompenaars and Hampden-Turner, 1998), and the validity of Hofstede's dimensions has been further confirmed by recent studies, such as that of van Oudenhoven (2001).

The attractiveness of Hofstede's approach is that it offers a well-validated instrument, available in a number of languages, that is supported by a growing literature (e.g., Vitell et al., 1993; Segal et al., 1993; Ralston et al., 1993; Søndergaard, 1994).

\section{Objectives and methodology}

As mentioned in the Literature Review, many studies highlighted the role of national culture in adopting NFWO. Specifically, the original work of Hofstede and the subsequent studies using his model provided 
some insight on whether and how national culture dimensions influence the adoption of advanced organizational practices.

Power distance has been shown to have an impact on different NFWO practices. In high power distance societies, power needs less legitimization than in low power distance societies (Pagell et al., 2005). Organizations from high power distance cultures are more accustomed to centralized and paternal leadership (Eylon and Au, 1999; Bates et al., 1995; van Oudenhoven, 2001), have many hierarchical levels (Bates et al., 1995; van Oudenhoven, 2001) and worker participation in decision processes is low (Newman and Nollen, 1996; van Oudenhoven, 2001). Uncertainty avoidance has proven to be positively related to the number and clarity of procedures and rules (Newman and Nollen, 1996), and a higher level of formalization (Harrison et al., 1994). As a consequence, the level of centralization of authority and the number of hierarchical levels are high (van Oudenhoven, 2001). Individualism is associated with the emphasis on personal contribution (Hofstede, 1983; Newman and Nollen, 1996). This aspect is reflected in such formal systems as the content of job descriptions (broad or narrow) (Bates et al., 1995), the assignment of problem-solving tasks to groups or to individuals (Bates et al., 1995; Harrison et al., 1994, van Oudenhoven, 2001), and the use of individual or group reward structures (Bates et al., 1995).

Finally, masculinity has also been proven to impact NFWO practices. Newman and Nollen (1996) point out that work units in more masculine cultures are higher performing if they have made more use of meritbased rewards for pay and promotion. In this context, it is not surprising that cultures having low levels of masculinity encountered affiliated work activities in the form of work teams earlier than countries with cultures displaying higher levels of masculinity (Harrison et al., 1994).

Aside from national culture, we know that macro-economic conditions and reforms, including privatization, deregulation, and globalization, also impact manufacturing strategies pursued by companies and, consequently, work organization (Mellor and Gupta, 2002). In particular, macro-economic indicators are positively correlated with the adoption of advanced manufacturing models (e.g., Dunning, 1988; Christmann et al. 1999; Sethi and Elango, 1999; Makino et al., 2004). First of all, the most economically advanced countries are generally more proactive in seeking new ways of organizing and managing their activities in order to improve their performance, be more flexible and respond to contextual changes (Mellor and Gupta, 2002). More developed countries also differ in terms of economic capabilities, such as expenditures on research and development as a percentage of GDP, that allow them to develop and adopt advanced manufacturing programs (Mellor and Gupta, 2002). In addition, in these countries companies are generally more oriented toward a balanced mix of performance, including employee satisfaction as a relevant measure. Often the adoption of NFWO is aimed at improving workplace conditions (Appelbaum et al. 2000, de Treville and Antonakis, 2006), thus being more diffused in those countries that pursue social sustainability. Finally, characteristics of the NFWO, such as empowerment, multiskilling, and autonomy in production, are usually more widespread in companies located in countries characterized by higher literacy levels. 
Despite this wide range of studies, to our best knowledge there is a lack of quantitative, empirical evidence to support a systemic and extensive view on this topic on a large scale.

In addition, the relative role played by the two constructs related to the country factor (i.e., economic development and national culture) is not widely discussed, apart from a few examples (e.g., Mellor and Gupta, 2002).

This paper aims at contributing to this stream of research by exploring on a wide empirical basis the role of the country factor, and, namely, the level of economic development and national culture dimensions, in the adoption of NFWO.

Our first research question is:

RQ1: To what extent do economic development and national culture influence the adoption of NFWO? In particular:

- What are the relative roles of economic development and national culture in explaining differences in the adoption of NFWO?

- How do the specific dimensions of the national culture influence the adoption of different NFWO practices?

Our second research question aims at exploring the different profiles of adoption of the NFWO model in groups of countries characterized by similar national cultures:

RQ2: To what extent and on which dimensions does the adoption of the NFWO model differ between groups of countries with different national cultures?

The assumption behind this research question, in line with the literature (e.g., Spina et al., 1996; Budhwar and Sparrow, 2002; European Commission, 2002; Ahmad and Schroeder, 2003; Bartezzaghi and Cagliano, 2007; Sousa and Voss, 2008; Vecchi and Brennan, 2009), is that the country variable does not influence the adoption of NFWO as a whole, but rather the single practices within the model that might be more or less aligned with the national setting. All the same, the culture dimensions measured through Hofstede's model are highly inter-related, and national culture is the result of the interaction among these dimensions. Thus, it is the mix of the different aspects, rather than the single dimension itself, that is expected to determine the specific profile of adoption of NFWO practices in each country. Following this line of reasoning, we want to give an overview of which practices are more or less adopted, depending on the cultural profile of different countries.

\section{Data, measures and method}

\section{Data collection}

To investigate the above research questions, we used data collected in the fourth edition of the International Manufacturing Strategy Survey (IMSS 4), a research project carried out in 2005 by a global network. This 
project, originally launched in 1992 by the London Business School and Chalmers University of Technology, studies manufacturing and supply chain strategies within the assembly industry (ISIC 28-35 classification) through a detailed questionnaire administered simultaneously in many countries by local research groups. The questionnaire investigates the strategies and activities performed at the plant level, so the target respondent is a plant, production or operations manager. Responses have been gathered in a unique global database (Lindberg et al., 1998). The sample consists of 660 firms from 21 countries, with an average response rate of $22 \%$. Two countries of the original database, namely China and Greece, have not been included in the analysis because data were not usable for the purpose of this study.

A survey research methodology is congruent with the aim of this study and aligned with other studies published in managerial literature on the role of cultural variables, based on Hofstede's framework (e.g., Newman and Nollen, 1996; Winch et al., 1997).

The distribution of the sample, in terms of country, industry and size, is shown in Tables 1 and 2.

Table 1 - Data descriptive statistics in terms of country and size

\begin{tabular}{|c|c|c|c|c|c|c|c|c|}
\hline Country & $\mathbf{N}$ & $\%$ & Country & $\mathbf{N}$ & $\%$ & Size* & $\mathbf{N}$ & $\%$ \\
\hline Argentina & 44 & 6.7 & $\begin{array}{l}\text { Italy } \\
\end{array}$ & 45 & 6.8 & $\overline{\text { Small }}$ & 384 & 58.2 \\
\hline Australia & 14 & 2.1 & Netherlands & 63 & 9.5 & Medium & 127 & 19.2 \\
\hline Belgium & 32 & 4.8 & New Zealand & 30 & 4.5 & Large & 126 & 19.1 \\
\hline Brazil & 16 & 2.4 & Norway & 17 & 2.6 & Missing & 23 & 58.2 \\
\hline Canada & 25 & 3.8 & Portugal & 10 & 1.5 & Total & 660 & 100.0 \\
\hline Denmark & 36 & 5.5 & Sweden & 82 & 12.4 & & & \\
\hline Estonia & 21 & 3.2 & Turkey & 35 & 5.3 & & & \\
\hline Germany & 18 & 2.7 & UK & 17 & 2.6 & & & \\
\hline Hungary & 54 & 8.2 & USA & 36 & 5.5 & & & \\
\hline Ireland & 15 & 2.3 & Venezuela & 30 & 4.5 & & & \\
\hline Israel & 20 & 3.0 & & & & & & \\
\hline & & & Total & 660 & 100.0 & & & \\
\hline
\end{tabular}

*Size: Small: less than 250 employees, Medium: 251-500 employees, Large: over 501 employees

Table 2 - Data descriptive statistics in terms of industry

\begin{tabular}{ccc|ccc}
\hline ISIC Code & Frequency & $\mathbf{\%}$ & ISIC Code & Frequency & $\mathbf{\%}$ \\
\hline 28 & 257 & 38.9 & 33 & 28 & 4.2 \\
29 & 135 & 20.5 & 34 & 64 & 9.7 \\
30 & 14 & 2.1 & 35 & 40 & 6.1 \\
31 & 78 & 11.8 & Missing & 8 & 1.2 \\
\cline { 3 - 6 } 32 & 36 & 5.5 & Total & $\mathbf{6 6 0}$ & $\mathbf{1 0 0 . 0}$ \\
\hline
\end{tabular}

\section{Operational definitions and constructs}

The measures of the relevant concepts of the research have been drawn from published research on similar subjects. In particular, we focused on the definition of NFWO provided by Cagliano et al. (2005) and derived from the European Commission (2002). According to this literature, NFWO is defined by practices related to: (i) the way work is organized within an operational activity, including teamwork, multiskilling, and job rotation; (ii) the way work is coordinated across the organization, including autonomy in performing 
job tasks, decentralized decision-making, and flat organizations; and (iii) supporting HRM policies, including training, and reward systems.

National culture has been measured using Hofstede’s (1991) model and dimensions.

Finally, the country's economic development was measured through the Gross National Income (GNI) per capita. According to past and recent studies (e.g., Adelman and Morris, 1965; King and Levine, 1993; World Bank, 2009; World Economic Forum, 2009), this measure shows very high correlations with other measures of economic development (e.g., institutions, markets and infrastructure development) and social welfare (e.g., health, literacy, school enrollment at higher, secondary and tertiary levels, and energy consumption per capita). Moreover, this measure has been widely used in a similar way in the literature on cross-country comparisons (e.g., Redding and Venables, 2004; Asafu-Adjaye, 2004; Kapopoulosa and Lazaretou, 2009). According to the constructs defined in the literature and discussed in the Literature Review, we selected the following items from the IMSS questionnaire to assess NFWO adoption.

The way work is organized is measured through Multiskilling (percentage of production workers considered to be multi-skilled in several operational tasks), Job Rotation (1-5 Likert-like scale asking how frequently production workers rotate between jobs or tasks), and Autonomy (1-5 Likert-like scale on the extent to which the workforce is autonomous in performing tasks).

The way work is coordinated is measured through Functional Teams (percentage of total workforce working in functional teams) and the average Span of Control (number of employees supervised by a single line of supervisors, in fabrication and in assembly).

HRM support is measured through Hours of Training (number of hours of training per year given to the regular workforce) and Group Incentives (1-5 Likert-like scale on the usage of group incentives, for both production and improvement activities).

After selecting the items, we performed a principal components factor analysis with Varimax rotation in order to highlight possible latent variables. The output of the factor analysis showed three factors and two single-item variables (see Table 3). The first factor, named Empowerment, encompasses Job Rotation, Multiskilling, and Autonomy. The second is the use of Group Incentives, together for production and improvement activities. The third is the Span of Control, jointly for production and assembly. All of the factor loadings are above 0.7 , and standardized Cronbach’s alpha are above 0.65 , highlighting a quite robust factor structure.

In contrast, Hours of training and Functional teams were treated as single-item constructs. This choice is considered acceptable for two reasons. First, some studies have shown that for consolidated constructs the validity of single- versus multiple-item measures does not show significant differences (Gardner et al., 1998; Bergkvist and Rossister, 2007). Second, both variables are measured on quantitative and objective scales (hours of training is measured in hours per employee, while the use of functional teams is measured as a percentage of total workforce), thus reducing the problem of construct validity and reliability. 


\begin{tabular}{|c|c|c|c|c|c|c|c|}
\hline Item Name & 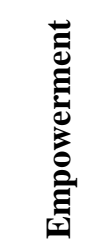 & 总总 & 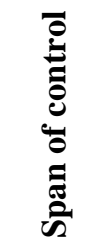 & 鄫 & 胥 & 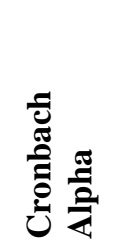 & స్ \\
\hline $\begin{array}{l}\text { Multiskilling* } \\
\text { Job rotation } \\
\text { Autonomy }\end{array}$ & $\begin{array}{l}0.811 \\
0.830 \\
0.656\end{array}$ & & & & & 0.666 & 1-5 Likert \\
\hline $\begin{array}{l}\text { Group incentives for } \\
\text { production } \\
\text { Group incentives for } \\
\text { improvement }\end{array}$ & & $\begin{array}{l}0.871 \\
0.904\end{array}$ & & & & 0.749 & 1-5 Likert \\
\hline $\begin{array}{l}\text { Span of control in } \\
\text { production } \\
\text { Span of control in assembly }\end{array}$ & & & $\begin{array}{l}0.897 \\
0.901\end{array}$ & & & 0.747 & $\begin{array}{l}\text { Number of } \\
\text { employees }\end{array}$ \\
\hline Training & & & & 0.980 & & - & $\begin{array}{l}\text { Hours of } \\
\text { training per } \\
\text { year }\end{array}$ \\
\hline Functional teams & & & & & 0.933 & - & $\begin{array}{l}\text { \% of } \\
\text { workforce in } \\
\text { teams }\end{array}$ \\
\hline
\end{tabular}

The new variables have been calculated as the average of the scores of single items for each factor, thus keeping the original scale.

Data measuring the relevant national variables (i.e., national culture and GNI per capita) have been drawn from specific databases and literature. In particular, Hofstede and Hofstede (2005) have been used to draw data on cultural variables, while GNI per capita has been taken from the World Bank (2005) database. GNI per capita and cultural variables are measured at the country level, while NFWO variables are measured at the company level. Therefore, while the firms from the same country may have different values for NFWO variables, all share the same values for GNI and cultural measures. In line with the prevalent literature on national culture influence (Newman and Nollen, 1996; Bates et al., 1995; Harrison et al., 1994), we grouped the countries in our study by means of a two-step cluster analysis (Ketchen and Shook, 1996) performed on the Hofstede's scores. This allowed us to deepen our analysis and take into consideration possible crosseffects of the cultural variables. The four resulting clusters (Table 4) are to a great extent overlapped to the clusters proposed by Hofstede $(1983,1991)$. 


\begin{tabular}{|c|c|c|c|c|c|c|}
\hline Cluster & Country & 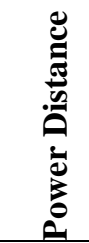 & 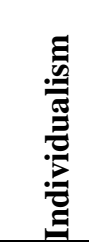 & 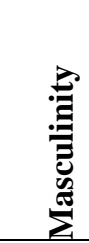 & 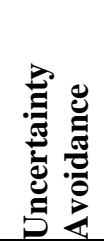 & 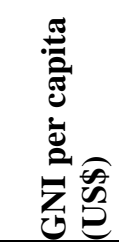 \\
\hline 1 & $\begin{array}{l}\text { Argentina } \\
\text { Hungary } \\
\text { Israel } \\
\text { Belgium } \\
\text { Italy } \\
\end{array}$ & 47.3 & 67.9 & 66.8 & 83.2 & 18,651 \\
\hline 2 & $\begin{array}{l}\text { Australia } \\
\text { Canada } \\
\text { Ireland } \\
\text { New Zealand } \\
\text { UK } \\
\text { USA } \\
\text { Germany } \\
\end{array}$ & 33.7 & 81.8 & 61.0 & 47.3 & 35,553 \\
\hline 3 & $\begin{array}{l}\text { Estonia } \\
\text { Denmark } \\
\text { Netherlands } \\
\text { Norway } \\
\text { Sweden }\end{array}$ & 31.7 & 72.9 & 12.0 & 39.5 & 40,220 \\
\hline 4 & $\begin{array}{l}\text { Portugal } \\
\text { Venezuela } \\
\text { Brazil } \\
\text { Turkey }\end{array}$ & 71.1 & 27.8 & 53.4 & 82.5 & 6,028 \\
\hline & Average & 42.2 & 67.3 & 45.4 & 60.2 & 28,037 \\
\hline
\end{tabular}

Cluster 1 comprises Latin European countries with an average value of GNI per capita. They have average-to-high values of cultural marks. Cluster 2 includes Anglo-Saxon countries with a high GNI per capita, and Germany. They show low Power Distance and high Individualism. Cluster 3 includes North European countries with the highest GNI per capita. They have the lowest level of Masculinity, low Power Distance and high Individualism. Finally, Cluster 4 includes emerging countries with the lowest GNI per capita. They have low Individualism and high Power Distance, and Uncertainty Avoidance.

Finally, according to the literature, we selected the company size as a relevant control variable to be considered in measuring NFWO adoption (e.g., Brewester, 1995; Sparrow, 1995; Spina et al., 1996; Budhwar and Sparrow, 2002; Shih et al., 2006).

We did not control for industry, both because previous studies using this variable showed mixed results (e.g., Bates et al., 1995; Delery and Doty, 1996; Spina et al., 1996; Ahmad and Schroeder, 2003; Way, 2002; Shah and Ward, 2003) and because the industries explored by the IMSS survey are already rather homogeneous in nature, the sample being restricted to the so-called "assembly industries" (ISIC 28-35).

In Table 5 all relevant variables for every country are reported. 
Table 5 - Statistics on relevant variables for single countries

\begin{tabular}{|c|c|c|c|c|c|c|c|c|c|c|c|}
\hline \multirow[b]{2}{*}{ Country } & \multicolumn{5}{|c|}{ NFWO } & \multirow[b]{2}{*}{ 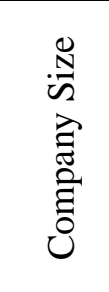 } & \multirow[b]{2}{*}{ 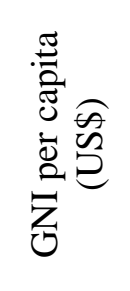 } & \multicolumn{4}{|c|}{ Cultural Variables } \\
\hline & 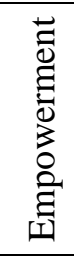 & 总. & $\begin{array}{l}\overline{0} \\
\tilde{E} \\
0 \\
0 \\
4 \\
0 \\
0 \\
\tilde{0} \\
\text { की }\end{array}$ & 冓吕 & 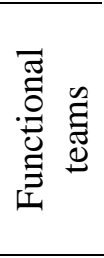 & & & 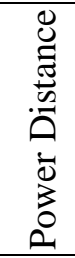 & 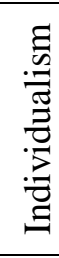 & 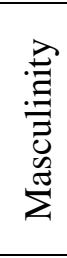 & 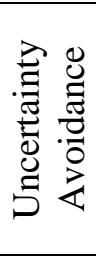 \\
\hline Argentina & 3.0 & 1.8 & 20.9 & 25.2 & 37.2 & 299.5 & 4,460 & 49 & 46 & 56 & 86 \\
\hline Australia & 2.9 & 1.6 & 12.1 & 31.9 & 21.6 & 59.9 & 33,120 & 36 & 90 & 61 & 51 \\
\hline Belgium & 3.1 & 1.4 & 23.8 & 23.6 & 35.2 & 396.2 & 36,140 & 65 & 75 & 54 & 94 \\
\hline Brazil & 3.1 & 3.2 & 33.1 & 32.0 & 47.7 & 822.6 & 3,890 & 69 & 38 & 49 & 76 \\
\hline Canada & 2.9 & 1.6 & 19.4 & 20.4 & 40.8 & 289.1 & 32,590 & 39 & 80 & 52 & 48 \\
\hline Denmark & 3.4 & 2.3 & 35.1 & 33.7 & 67.1 & 327.2 & 48,330 & 18 & 74 & 16 & 23 \\
\hline Estonia & 2.8 & 2.5 & 15.3 & 17.0 & 43.8 & 98.0 & 9,530 & 40 & 60 & 30 & 60 \\
\hline Germany & 3.3 & 2.3 & 23.2 & 22.1 & 51.2 & 682.0 & 34,870 & 35 & 67 & 66 & 65 \\
\hline Hungary & 2.7 & 2.7 & 17.4 & 12.8 & 62.1 & 290.4 & 10,210 & 46 & 80 & 88 & 82 \\
\hline Ireland & 2.4 & 3.0 & 15.2 & 27.8 & 59.0 & 586.2 & 41,140 & 28 & 70 & 68 & 35 \\
\hline Israel & 2.9 & 2.1 & 11.3 & 27.2 & 66.8 & 139.1 & 18,580 & 13 & 54 & 47 & 81 \\
\hline Italy & 3.1 & 1.9 & 21.3 & 27.1 & 37.1 & 433.8 & 30,250 & 50 & 76 & 70 & 75 \\
\hline Netherlands & 3.1 & 1.7 & 19.6 & 22.5 & 57.8 & 256.9 & 39,340 & 38 & 80 & 14 & 53 \\
\hline New Zealand & 3.3 & 1.4 & 10.5 & 28.5 & 45.5 & 110.4 & 25,920 & 22 & 79 & 58 & 49 \\
\hline Norway & 3.4 & 1.5 & 12.4 & 22.6 & 46.0 & 118.8 & 60,890 & 31 & 69 & 8 & 50 \\
\hline Portugal & 3.1 & 2.3 & 19.4 & 45.2 & 54.3 & 205.3 & 17,190 & 63 & 27 & 31 & 104 \\
\hline Sweden & 3.7 & 2.0 & 33.7 & 24.2 & 69.6 & 444.3 & 40,910 & 31 & 71 & 5 & 29 \\
\hline Turkey & 2.9 & 2.1 & 32.4 & 22.4 & 43.5 & 745.2 & 4,750 & 66 & 37 & 45 & 85 \\
\hline UK & 3.4 & 1.6 & 8.8 & 27.1 & 41.3 & 137.4 & 37,750 & 35 & 89 & 66 & 35 \\
\hline USA & 2.7 & 2.0 & 16.9 & 21.9 & 32.0 & 511.0 & 43,560 & 40 & 91 & 62 & 46 \\
\hline Venezuela & 2.9 & 2.4 & 13.8 & 33.6 & 43.2 & 445.7 & 4,940 & 81 & 12 & 73 & 76 \\
\hline Mean & 3.1 & 2.0 & 20.9 & 24.4 & 50.4 & 358.3 & 27,541 & 43 & 65 & 49 & 62 \\
\hline
\end{tabular}

\section{Data analysis}

As a first step of the analysis, we measured the correlations between the independent variables (cultural dimensions, GNI, and company size) and NFWO measures (Table 6). We notice significant correlations among cultural variables and between these and both GNI per capita (as already stated by Hosftede, 1983) and company size. Moreover, NFWO variables are positively correlated with each other, thus suggesting frequent joint adoptions. 
Table 6 - Correlations among the independent variables and NFWO variables

\begin{tabular}{|c|c|c|c|c|c|c|c|c|c|c|c|}
\hline & \multicolumn{5}{|c|}{ NFWO } & \multicolumn{4}{|c|}{ Cultural Variables } & \multirow[b]{2}{*}{ 怘 } & \multirow[b]{2}{*}{ 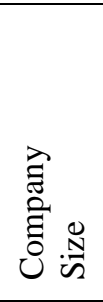 } \\
\hline & 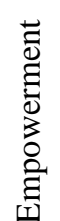 & 密. & 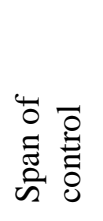 & 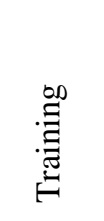 & 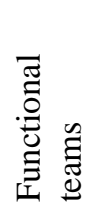 & 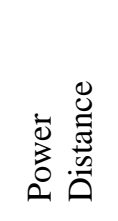 & 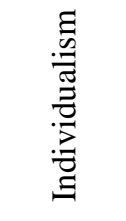 & 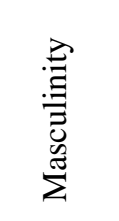 & 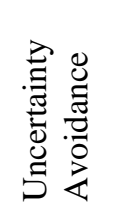 & & \\
\hline Empowerment & 1 & .021 & .094 & $.178^{*}$ & $.222^{*}$ & $-.152 *$ & .043 & $-.260 *$ & $-.229 *$ & $.208^{*}$ & -.006 \\
\hline Group incentives & & 1 & $.152^{*}$ & $.121^{*}$ & $.195 *$ & .078 & $-.128 *$ & .079 & .041 & $-.150 *$ & $.094 *$ \\
\hline Span of control & & & 1 & -.014 & $.180^{*}$ & .012 & -.076 & $-.255^{*}$ & $-.125^{*}$ & .080 & $.293^{*}$ \\
\hline Training & & & & 1 & $.096 *$ & .003 & $-.114^{*}$ & -.065 & -.039 & .040 & $.118^{*}$ \\
\hline Functional teams & & & & & 1 & $-.172 *$ & .026 & $-.176^{*}$ & $-.150 *$ & $.082 *$ & $.115^{*}$ \\
\hline Power Distance & & & & & & 1 & $-.605^{*}$ & $.407 *$ & $.697 *$ & $-.592 *$ & $.182^{*}$ \\
\hline Individualism & & & & & & & 1 & -.059 & $-.471 *$ & $.661^{*}$ & $-.129 *$ \\
\hline Masculinity & & & & & & & & 1 & $.583^{*}$ & $-.531 *$ & .030 \\
\hline $\begin{array}{l}\text { Uncertainty } \\
\text { Avoidance }\end{array}$ & & & & & & & & & 1 & $-.727^{*}$ & .040 \\
\hline GNI per capita & & & & & & & & & & 1 & -.050 \\
\hline Company Size & & & & & & & & & & & 1 \\
\hline
\end{tabular}

Next, in order to answer our first research question we adopted a hierarchical linear regression. In this analysis, NFWO measures are considered dependent variables, whereas control variables and cultural variables are considered independent. For each NFWO we applied the following procedure:

1. In the first step, we considered only Size as a control variable

2. In the second step, we run a stepwise regression on the GNI per capita and cultural variables, keeping size as a control variable in the model.

Thanks to the stepwise method, we could point out only the most meaningful variables among GNI and cultural measures. Indeed, the stepwise method enters one new variable at a time, selecting the most significant ones and continuing until no more significant variables are found.

Each step of the procedure has been controlled for multicollinearity by checking the variance inflation factor (VIF) of the independent variables. R-square change was also taken into consideration in order to evaluate whether or not the new model has more explanatory power than the previous: R-square change is always significant. VIF is always lower than 2.2, and the cut-off point is usually between 5 and 10 (Menard, 1995; Neter et al., 1989; Hair et al., 1995). Therefore, multicollinearity is not considered an issue for any model.

To answer the second research question, we performed an ANOVA analysis to test differences among the four clusters of countries in the adoption of NFWO. 


\section{Results}

\section{Regression analysis}

Results of the regression analysis are reported in Table 7.

Table 7 - Stepwise regression results

\begin{tabular}{|c|c|c|c|c|c|c|c|}
\hline $\begin{array}{l}\text { Dependent } \\
\text { variable }\end{array}$ & Independent variables & Beta & $\mathrm{t}$ & Sig. & VIF & R-square & $\begin{array}{l}\text { Sig. F } \\
\text { Change }\end{array}$ \\
\hline \multirow[t]{9}{*}{ Empowerment } & 1 Constant & & 67.145 & 0.001 & & 0.000 & 0.892 \\
\hline & Size & -0.006 & -0.136 & 0.892 & 1.000 & & \\
\hline & 2 Constant & & 48.052 & 0.001 & & 0.073 & 0.001 \\
\hline & Size & 0.003 & 0.086 & 0.932 & 1.001 & & \\
\hline & Masculinity & -0.270 & -6.845 & 0.001 & 1.001 & & \\
\hline & 3 Constant & & 36.168 & 0.001 & & 0.081 & 0.026 \\
\hline & Size & 0.008 & 0.200 & 0.841 & 1.004 & & \\
\hline & Masculinity & -0.202 & -4.081 & 0.001 & 1.594 & & \\
\hline & Uncertainty Avoidance & -0.111 & -2.235 & 0.026 & 1.598 & & \\
\hline \multirow[t]{9}{*}{ Group Incentives } & 1 Constant & & 29.973 & 0.001 & & 0.009 & 0.001 \\
\hline & Size & 0.094 & 2.207 & 0.028 & 1.000 & & \\
\hline & 2 Constant & & 20.564 & 0.001 & & 0.028 & 0.001 \\
\hline & Size & 0.083 & 1.962 & 0.050 & 1.006 & & \\
\hline & GNI per capita & -0.140 & -3.284 & 0.001 & 1.006 & & \\
\hline & 3 Constant & & 9.543 & 0.001 & & 0.038 & 0.018 \\
\hline & Size & 0.085 & 2.010 & 0.045 & 1.006 & & \\
\hline & GNI per capita & -0.246 & -3.997 & 0.001 & 2.134 & & \\
\hline & Uncertainty Avoidance & -0.147 & -2.382 & 0.018 & 2.131 & & \\
\hline \multirow[t]{5}{*}{ Span of control } & 1 Constant & & 19.103 & 0.001 & & 0.086 & 0.001 \\
\hline & Size & 0.293 & 6.066 & 0.001 & 1.000 & & \\
\hline & 2 Constant & & 16.288 & 0.001 & & 0.155 & 0.001 \\
\hline & Size & 0.306 & 6.578 & 0.001 & 1.003 & & \\
\hline & Masculinity & -0.264 & -5.672 & 0.001 & 1.003 & & \\
\hline \multirow[t]{9}{*}{ Training } & 1 Constant & & 19.696 & 0.001 & & 0.014 & 0.005 \\
\hline & Size & 0.118 & 2.838 & 0.005 & 1.000 & & \\
\hline & 2 Constant & & 8.707 & 0.001 & & 0.023 & 0.020 \\
\hline & Size & 0.105 & 2.519 & 0.012 & 1.017 & & \\
\hline & Individualism & -0.098 & -2.339 & 0.020 & 1.017 & & \\
\hline & 3 Constant & & 9.264 & 0.001 & & 0.043 & 0.001 \\
\hline & Size & 0.101 & 2.454 & 0.014 & 1.018 & & \\
\hline & Individualism & -0.216 & -3.990 & 0.001 & 1.738 & & \\
\hline & GNI per capita & 0.182 & 3.391 & 0.001 & 1.716 & & \\
\hline \multirow[t]{14}{*}{$\begin{array}{l}\text { Functional } \\
\text { Teams }\end{array}$} & 1 Constant & & 24.304 & 0.001 & & 0.013 & 0.006 \\
\hline & Size & 0.115 & 2.760 & 0.006 & 1.000 & & \\
\hline & 2 Constant & & 15.816 & 0.001 & & 0.054 & 0.001 \\
\hline & Size & 0.152 & 3.650 & 0.001 & 1.033 & & \\
\hline & Power Distance & -0.204 & -4.903 & 0.001 & 1.033 & & \\
\hline & 3 Constant & & 15.965 & 0.001 & & 0.064 & 0.014 \\
\hline & Size & 0.147 & 3.532 & 0.001 & 1.036 & & \\
\hline & Power Distance & -0.160 & -3.540 & 0.001 & 1.228 & & \\
\hline & Masculinity & -0.109 & -2.456 & 0.014 & 1.189 & & \\
\hline & 4 Constant & & 10.150 & 0.001 & & 0.072 & 0.031 \\
\hline & Size & 0.151 & 3.649 & 0.001 & 1.039 & & \\
\hline & Power Distance & -0.213 & -4.153 & 0.001 & 1.596 & & \\
\hline & Masculinity & -0.154 & -3.148 & 0.002 & 1.450 & & \\
\hline & GNI per capita & -0.120 & -2.161 & 0.031 & 1.865 & & \\
\hline
\end{tabular}

The results of our analyses show that GNI and cultural measures provide a significant improvement for the R-square, compared to the first model, which includes only the company size for all NFWO practices. In 
particular, it is possible to notice that GNI, cultural measures or both have significant influence on practice adoption, depending on the NFWO practice considered.

GNI per capita is significant for Group Incentives, Training, and Functional Teams. Quite interestingly, whereas in the case of Training this effect is positive, for Group Incentives and Functional teams the link is negative. This suggests that more advanced countries do not always adopt new organizational models to a greater extent than less advanced countries.

The results of the regression also show that at least some dimensions of national culture always have a significant influence on the adoption of NFWO. These measures, when significant, always have a negative effect, i.e., Hofstede's measures of cultural variables generally have an inhibitor effect on NFWO adoption.

Specifically, Masculinity negatively affects Empowerment, Span of Control, and Functional Teams; Uncertainty Avoidance negatively affects Empowerment and Group Incentives; Individualism negatively affects Training; Power Distance negatively affects Functional Teams.

ANOVA

Table 8 reports the results of the ANOVA, the average scores of the clusters on the different NFWO and the cluster they are significantly different from.

Cluster 3 has a significantly higher use of Empowerment compared to Cluster 1 and 4. Cluster 4 adopts Group Incentives more than Cluster 2. Cluster 3 has a broader Span of Control than Cluster 3 and 4. Cluster 4 uses Training more than Cluster 1. Finally, Cluster 3 has the highest adoption of Functional Teams than everyone else.

Table 8 - NFWO adoption means and differences among clusters (in bold the highest scores and in italic the lowest, for each variable).

\begin{tabular}{cccccc}
\hline Cluster & Empowerment & $\begin{array}{c}\text { Group } \\
\text { Incentives }\end{array}$ & Span of Control & Training & $\begin{array}{c}\text { Functional } \\
\text { Teams }\end{array}$ \\
\hline 1 & 2.9 & 2.0 & 19.5 & 21.7 & 47.8 \\
& 3 & 1.8 & 15.4 & 24.7 & 41.1 \\
\hline 2 & 3.0 & 4 & $3 ; 4$ & & 3 \\
\hline 3 & & 2.0 & $\mathbf{2 5 . 6}$ & 24.5 & $\mathbf{6 1 . 3}$ \\
& 3.4 & 2.4 & 24.5 & 30.0 & 45.3 \\
\hline 4 & $1 ; 4$ & 2 & 2 & 1 & 3 \\
\hline ANOVA Sig. & 3.0 & $\mathbf{0 . 0 1 7}$ & $\mathbf{0 . 0 0 1}$ & $\mathbf{0 . 0 3 7}$ & $\mathbf{0 . 0 0 1}$ \\
\hline
\end{tabular}

\section{Discussion}

The results presented in the previous section allow us to answer the research questions of the paper.

First of all, the influence of the country factor on the adoption of NFWO practices is strongly supported by our empirical evidence because all the regression models show a significant increase in explanatory power, when including some country factor in the model in addition to the control variable, i.e., company 
size. This result is aligned with the prevalent literature dealing with this subject (e.g., Brewester, 1995; Sparrow, 1995; Spina et al., 1996; Budhwar and Sparrow, 2002; Shih et al., 2006). However, the contribution of our results to the existing research consists in the test of the significance of this link on a relatively large number of countries in different economic areas.

Moreover, our results offer a deeper understanding of the different facets of the country factor that play a role in the adoption of NFWO. In fact, whereas at least some cultural variables are linked to all the different practices of NFWO, the level of economic development, measured through the GNI per capita, is significant only in some of the models analyzed, namely, for Group Incentives, Training and Functional Teams. We can thus conclude that, in relative terms, national culture is on average more important than economic development in fostering or hampering the adoption of NFWO.

It is also worthwhile to notice that the level of economic development does not always positively influence the adoption of NFWO practices. In fact, whereas the link is positive for Training, it is negative for Group Incentives and Functional Teams. This result can be interpreted in light of the high correlation of GNI with the other independent variables (see Table 5). In particular, the positive correlation between GNI and Individualism suggests that both team work and Group Incentives are less used in those countries having high economic welfare because they are generally characterized by high levels of Individualism. Actually, for what concerns Functional Teams, this result is weak. In fact, the sign of the regression coefficient is the opposite of the correlation shown in Table 5. This is due to the weakness of the correlation between the two variables. In any case, it is important to conclude that, differently from some results put forward by the literature about the difficulty of spreading NFWO across lower developed countries (e.g., Sethi and Elango, 1999; Makino et al., 2004), we can assert that at least some of the practices are not influenced or even influenced positively by the low level of economic development. Given the type of countries analyzed in this paper and the year in which data have been gathered, we speculate that recently industrialized countries have achieved the economic conditions - as well as the social and labor market characteristics - necessary to adopt the most advanced work design and HRM practices.

As far as national culture is concerned, our results show that all cultural variables influence at least one of the NFWO practices, but there is no dominant dimension to explain a higher or lower orientation to NFWO overall. We discuss below the results of each regression model, referring to the different NFWO practices.

Empowerment. This practice is negatively affected by Masculinity and Uncertainty Avoidance. Empowered employees are expected to display high levels of satisfaction as a result of higher involvement and discretion in their work. Feminine cultures, which place a higher value on the quality of life and, consequently, the quality of work (Hofstede, 1980, 1983), are therefore better recipients for work practices characterized by high job rotation and autonomy. At the same time, empowerment gives employees discretion and responsibilities in their activities, expecting from them the ability to cope with problematic situations. Multiskilling and Job Rotation, included in the Empowerment construct, reduce the level of repetition and certainty of tasks to be accomplished. Therefore, workers in high uncertainty avoidance 
countries prefer lower levels of job rotation, to have stable tasks and to keep stable relationships with colleagues, and lower levels of multiskilling, autonomy and delegation, to better know what they are expected to do. In contrast to some of the results in the literature (Newman and Nollen, 1996; van Oudenhoven, 2001), Power Distance is not significantly related to Empowerment. This is an interesting result, in line with the study of Eylon and Au (1999), that suggests a complex relationship between Power Distance and Empowerment, showing that Empowerment works less well - but is not less used - in high Power Distance cultures because workers may not possess the background and ability to perform well when tasks are less structured, information more limited and responsibility higher. Finally, Individualism also does not significantly affect Empowerment because the emphasis on personal contribution -emphasized in such cultures - may imply broader and richer job descriptions (Bates et al., 1995), i.e., Empowerment, but might also be contrary to the collaboration and team behavior that is required in empowered work settings.

Span of Control. This NFWO practice is negatively affected by Masculinity, whereas it is not significantly related to Power Distance, in contrast to the finding in the prevalent literature (Hofstede, 1983 and 1991; Bates et al., 1995; van Oudenhaven, 2001). The interpretation is not straightforward. First of all, we might observe that Span of Control has some peculiarities compared to other measures of hierarchy, such as the number of hierarchical levels. In fact, we might assert that in higher Power Distance cultures, power needs less legitimization (Pagell et al., 1995) and this facilitates the management of a larger number of employees compared to situations with more balanced power distribution. Thus, a higher Span of Control does not necessarily mean lower hierarchy in these cases. On the other hand, the link between Span of Control and more Feminine cultures might be interpreted as a consequence of the lower emphasis in these cultures on making a career compared to the importance of social relationships at work (van Oudenhoven, 2001). In fact, higher Span of Control and the consequently flatter organizational structures generally reduce the chances of individuals progressing in their career paths. A further possible explanation is that Masculinity leads to lower use of delegation, autonomy (see Empowerment), and team work (see Functional Teams), which in turn reduce the possibilities of increasing the Span of Control.

Group Incentives. This practice is negatively affected by Uncertainty Avoidance. The negative effect of Uncertainty Avoidance can be explained by the workers' resistance to link their salaries to the performance of a larger group because Group Incentives make the wages for the single worker less predictable (Bates et al., 1995). The expected effect of Individualism over Group Incentives - although present in the analysis of correlations - is not significant in the regression model, suggesting a very weak link. Indeed, individualistic cultures tend to emphasize the remuneration linked to individual contributions more than the group (Newman and Nollen, 1996); however, the cause-effect relationship can also be the opposite because Individualism is clearly an obstacle for the adoption of teamwork (Hofstede, 1983 and 1991; Bates et al., 1995, van Oudenhoven, 2001). However, further analyses are necessary to assess whether or not results change when companies use individual incentives or overall bonuses based on outcomes in place of group incentives. 
Functional teams. This NFWO practice is negatively affected by Masculinity and Power Distance. As stated in the literature (e.g., Hofstede, 1983, 1991 and 1993; van Oudenhaven, 2001), Masculinity tends to reduce Teamwork (e.g., because people tend to place more importance on their personal success and less importance on rewarding job practices and social relationships). Power distance generally reduces workers' participation (Newman and Nollen, 1996) and autonomy (van Oudenhaven, 2001), thus eliminating one of the major reasons for teamwork. Moreover, in high power distance societies, organizations prefer coercive and referent power more than balanced power structures such as teams.

The absence of the link between Functional Teams and Individualism is however not aligned to the prevalent literature (Hofstede, 1983 and 1991; Bates et al., 1995; van Oudenhaven, 2001). This is confirmed by both the correlation and the regression analysis, meaning that it is not even an effect of the interaction of multiple variables. Therefore, we can conclude that Functional Teams are currently adopted independently from Individualism, probably as a consequence of their broad diffusion in management practice (no country shows very low values), whereas Masculinity and Power Distance do play a role. However, this does not reveal anything about the effectiveness of Functional Teams in Individualistic cultures, which we still can expect to be questionable.

Training. This NFWO practice is negatively affected by Individualism. This result is rather surprising because the literature suggest a possible positive link, as a consequence of the higher emphasis on personal contribution (Newman and Nollen, 1996) and job enrichment (Bates et al., 1995) in high individualistic cultures. However, other studies underscored the preference for different types of training depending on the level of individualism. In particular, Luo (2007) predicted a preference for continuous learning as a mode of training in non-corporatist (i.e., individualistic) cultures. All the same, Earley (1994) proved the higher effectiveness of self-focused training for individualistic cultures and of group-focused training in collectivist cultures. Thus, we may interpret our result by saying that formal training is typically more used in more collectivist cultures, in association with the use of teamwork, with the aim of increasing group capability of performing tasks. This interpretation is partly supported by the significant correlation between Training and Functional Teams (Table 5), but needs further analysis to be confirmed.

In summary, the answer to our first research question (RQ1) is that both economic development and national culture play a significant role in the adoption of NFWO; there is not a clear dominance of one dimension over the other, even if national culture appears to be relatively more important overall compared to economic development. In addition, among the different variables characterizing national culture, no one single variable is responsible for the prevalent effect on practice adoption. Rather, it is the mix of facets of the national culture that influences the higher or lower inclination to the adoption of NFWO. One additional contribution of our study is the evidence of the impact of some of the less-studied cultural dimensions - i.e., Masculinity and Uncertainty Avoidance - on the adoption of advanced work design and HRM practices. In fact, these variables appear to have quite a relevant role in influencing NFWO adoption - with Feminine and low Uncertainty Avoidance settings being more suited to them. 
This leads us to the answer to the second question, through the results of the ANOVA among the four clusters. The cluster that shows the higher overall and balanced orientation to NFWO, especially on advanced work organization practices, is Cluster 3, which includes North European countries showing low scores on all cultural variables except Individualism. This result is not surprising, as these countries have been among the first in the western world to experience new production models that departed from Taylorism (e.g., Berggren, 1994; Thompson and Wallace, 1996; Cagliano et al., 2001). However, it is important to demonstrate that not only can this historical path explain the higher orientation to NFWO but also some specific traits of the national culture that characterize these countries. This model of adoption of NFWO is aligned with the "village market" model proposed by Hofstede (1983), characterized by no decisive hierarchy, flexible rules, and a resolution of problems by negotiation.

In contrast, Cluster 4, including Emerging countries characterized by low Individualism, high Power Distance and Uncertainty Avoidance, shows the highest scores on advanced HRM practices such as Group Incentives and Training, while lagging behind on work redesign. The low level of Individualism seems to support the implementation of policies oriented toward fostering group rather than individual improvement, in line with the results from our regression analysis. Interestingly, these countries show the lowest level of GNI per capita, thus also strengthening our result for the diffusion of NFWO in emerging countries.

Low levels of Power Distance and Uncertainty Avoidance, high levels of Masculinity, and Individualism characterize the cultural profile of Cluster 2, which is made up mainly of Anglo-Saxon countries. Here, NFWO practices seem to be mainly limited to the use of Empowerment and Training, and thus are strongly inclined toward the "opportunity to participate" and the "skills" of the employees (e.g., Bailey, 1993 or Appelbaum et al., 2000). Instead, the relatively high level of Masculinity and Individualism hamper the introduction of Teamwork, Group Incentives, and flat structures.

Finally, the cultural profile of Cluster 1 - Latin European countries with average scores on all of the cultural variables, corresponds to an average adoption of all NFWO practices.

Overall, these results lead to an answer to the second research question (RQ2) by revealing that the dominant culture of one country determines the specific profile of NFWO adoption practices. In particular, countries with similar cultural traits seem to choose similar types of job redesign, coordination mechanisms and HRM support practices because the implementation of these practices is more or less fostered (or hampered) by a number of different factors, among which cultural variables play an important role. The coherence between the organizational design of the company and the external environment thus requires that, although oriented in general principle toward NFWO, one company selects and implements those practices that are more aligned with the specific cultural setting in which it operates. This result is aligned with the configurational perspective in the organizational literature, which contends that advanced organizational practices are not good "per se” (as maintained by the universal approach; e.g., Huselid, 1995; Applebaum et al., 2000), but should be implemented in internally and externally coherent bundles (MacDuffie, 1995). 


\section{Conclusions}

This paper aimed at studying on a wide empirical basis and across a relevant number of countries the effects of the national culture and economic development on the adoption of NFWO practices. In line with most of the literature on the subject, we expected to find variations in the adoption of the NFWO model, depending on the two explanatory variables. The results of our analysis provide wide empirical support for the significance of the influence of both economic development, measured through the GNI per capita of the country, and national culture, measured by the Hofstede framework, on the adoption of all NFWO practices. Whereas economic development explains the adoption of only some NFWO practices, national culture always plays a relevant role. Therefore, the first conclusion of our research is that in present times the level of economic development plays a minor role in explaining the diffusion of advanced organizational practices. This result is relatively new compared to the wide stream of literature that interpreted the differential diffusion of new organizational models on the basis of economic development of the countries (Makino et al., 2004; Mellor and Gupta, 2002). The socio-economic gaps among countries - at least considering old and new industrialized countries - appear to be no more a barrier to the adoption of innovative organizational design, whereas the dominant culture in the country does play an important role in shaping the way this innovation is implemented.

Arriving at the second country-specific variable, we can conclude that there is no cultural profile or single cultural dimension that is dominant in fostering the adoption of the overall NFWO model. Rather, each type of cultural profile determines different ways of adopting the model. This result is a possible advancement compared to the literature based on the Hosftede framework, in which organizational differences are mainly traced back to the dimensions of power distance and uncertainty avoidance (Winch et al., 1997; Eylon and $\mathrm{Au}, 1999)$, because our analyses also underscore the relevant role of individualism and masculinity in shaping specific NFWO models.

Our results also allow for a better understanding of the independent and interdependent roles of the cultural dimensions on the adoption of the NFWO. For example, North European countries, characterized by low levels on all cultural marks except for individualism, tend to rely on empowerment, teamwork and flat organizations, whereas Latin American countries, with low individualism but high power distance, masculinity and uncertainty avoidance, tend to rely more on advanced HRM practices.

In general, our results contribute to the recent attempt to include several contextual variables (see e.g., Sousa and Voss, 2008) in the study of operations management, including those that are country-specific. In particular, disentangling the various facets of the country variable allows for obtaining more general results, compared to the study of the differences between specific countries. The relevance of the contribution of our paper to the research is also related to the consideration of the cultural variable, which is rather neglected in Operations Management studies (Appelbaum, et al., 2000; Spina et al., 1996; MacDuffie, 1995).

We claim that our results are also of interest for practitioners because managers - especially of multinational companies - are often faced with the challenge of transferring organizational models and 
practices across countries, and we provide some insights on how to take into account cultural variables when adapting NFWO to different countries. In particular, managers have to not only consider the variations to the NFWO model that are expected to better fit the various cultures characterizing the counties they are operating in, but also be aware of the difficulties that can derive from some cultural traits to the diffusion of some organizational practices, in order to overcome them with appropriate change management and training actions.

This research has some important limitations. First of all, as with any quantitative study, there is a lack of detailed information and knowledge about how the practices should be adapted and configured to fit the level of economic development and the specific national culture. In particular, as it has been put forward in the Discussion section, in many cases the link between cultural dimensions and NFWO practices is more related to the way the practice is used rather than the extent of adoption.

Moreover, it would be rather important to test the effect on operational and business performance of the different variations of NFWO implementation, to assess whether or not there are dominant variations. This would provide further support to practitioners by helping them to understand when and how to overcome the limitations coming from the country-specific characteristics, to target a more complete adoption of NFWO models.

Finally, the Hosftede framework, although being the most diffused, presents some limitations, such as the limited number of variables and the way they are measured, and therefore further analyses might try to compare the results obtained in this paper with the results that would be obtained using different national culture frameworks (e.g., the GLOBE framework, Schwartz, 1995).

\section{References}

Adelman, I. and Morris, C.T. (1965), “A Factor Analysis of the Interrelationship Between Social and Political Variables and Per Capita Gross National Product”, The Quarterly Journal of Economics, Vol. 79 No. 4, pp. 555-578.

Åhlström, P. and Karlsson, C. (2000), "Sequences of manufacturing improvement initiatives: the case of delayering”, International Journal of Operations \& Production Management, Vol. 20 No.11, pp. 12591277.

Ahmad, S. and Schroeder, R. (2003), “The impact of human resource management practices on operational performance: recognizing country and industry differences”, Journal of Operations Management, Vol. 21, pp. 19-43.

Appelbaum, E., Bailey, T., Berg, P. and Kalleberg, A (2000), Manufacturing advantage: why highperformance work systems pay off, ILR Press, Ithaca.

Asafu-Adjay, J. (2004), “Income inequality and health: a multi-country analysis”, International Journal of Social Economics, Vol. 31 No. 1/2, pp. 195-207. 
Bartezzaghi, E. and Cagliano, R. (2007), “The diffusion of new forms of work organization in Italy: an open debate”, in Garibaldo F. and Telljohann V., New Forms of Work Organisation and Industrial Relations in Southern Europe, Peter Lang, Berlin, pp. 223-240

Bates, K.A., Amundson, S.D., Schroeder, R.G. and Morris, W.T. (1995), “The Crucial Interrelationship Between Manufacturing Strategy and Organizational Culture”, Management Science, Vol. 41 No. 10, pp. 1565-1580.

Bailey, T.1993. Discretionary effort and the organization of work: Employee participation and work reform since Hawthorne. Working paper, Columbia University, New York.

Berggren, C. (1994), “Nummi vs. Uddevalla”, Sloan Management Review, Winter, pp. 37-49.

Bergkvist, L. and Rossiter, J.R. (2007), “The Predictive Validity of Multiple-Item Versus Single-Item Measures of the Same Constructs”, Journal of Marketing Research, Vol. 44, May, pp. 175-184.

Brewster, C. (1995), “Towards a European model of human resource management”, Journal of International Business, Vol. 26 No. 1, pp. 1-21.

Brödner, P. and Latniak, E. (2002), "Sources of Innovation and Competitiveness: National Programmes Supporting the Development of Work Organisation”, Report to DG Employment and Social Affairs.

Budwhar, P.R. and Sparrow, P. S. (2002), “An integrative framework for understanding cross-national human resource management practices”, Human Resource Management Review, Vol. 12 No. 1, pp. 377403.

Bullinger, H.J. (1997), "Paradigm change in production management: New lead concepts towards higher competitiveness in technology based enterprises”, International Journal of Production Economics, Vol. 52 No. 1/2, pp. 215-225.

Burgess, K. (1995), “Prospering in a global economy”, Journal of the Operational Research Society, Vol. 46 No. 5, pp. 553-61.

Cagliano, R., Blackmon, K. and Voss, C. (2001), "Small Firms under Microscope: international differences in production/operations management practices and performance”, Integrated Manufacturing Systems, Vol. 12 No. 7, pp. 469-482.

Cagliano, R. Caniato, F., Saini, S., Spina, G. (2005), "New forms of work organisation and the evolution of the labour market”, Proceedings of the 12th EurOMA Conference, Budapest (HU), 19-21 June 2005.

Christmann, P., Day, D.L. and Yip, G.S. (1999), "The relative influence of country conditions, industry structure and business strategy on MNC subsidiary performance”, Journal of International Management, Vol. 5 No. 1,, pp. 241-265. 
Clarke, C. (2005), Automotive production systems and standardization. From Ford to the case of MarcedesBenz, Physica Verlag, Heidelberg.

de Treville, S. and Antonakis, J, (2006), “Could lean production job design be intrinsically motivating? Contextual, configurational, and levels-of-analysis issues”, Journal of Operations Management, Vol. 24 No. 1, pp. 99-123.

Delaney, J.T. and Huselid, M.A. (1996), "The impact of human resource management practices on perceptions of organizational performance”, Academy of Management Journal, Vol. 39 No. 4, pp. 949969.

Dorfman, P.W. and Howell, J.P. (1988), “Dimensions of national culture and effective leadership patterns: Hofstede revisited”, in Farmer R.N. and McGoun E.G. (Eds), Advances in international comparative management, JAI, New York, pp. 127-150.

Dunning, JH. (1988), Explaining International Production, Allen \& Unwin, London.

Earley, P.C. (1994), “Self or Group? Cultural Effects of Training on Self-Efficacy and Performance”, Administrative Science Quarterly, Vol. 39, No. 1, pp. 89-117.

European Commission (2002), New Form of Work Organization: The Obstacles to a Wider Diffusion, Final Report, Business Decision Limited, October.

Ettlie, J.E. (1997), "Quality, technology, and global manufacturing”, Production and Operations Management, Vol. 6 No. 2, pp. 150-66.

Eylon, D. and Au, K. (1999), "Exploring empowerment cross- cultural differences along the power distance dimension”, International Journal of Intercultural Relations, Vol. 23, No. 3, pp. 373-385.

Gardner, D.G., Cummings, L.L., Dunham, R.B. and Pierce, J.L. (1998), “Single-Item Versus Multiple-Item Measurement Scales: An Empirical Comparison”, Educational and Psychological Measurement, Vol. 58 No.6, pp. 898-915.

Gonzalez-Benito, J. (2005), “A study of the effect of manufacturing proactivity on business performance”, International Journal of Operations \& Production Management, Vol. 25 No. 3, pp. 222-241.

Guest, D.E. (1997), “Human resource management and performance: a review and research agenda”, The International Journal of Human Resource Management, Vol. 8 No. 3, pp. 263-276.

Gunn, T.G. (1987), Manufacturing for Competitive Advantage: Becoming a World Class Manufacturer, Bullinger Publishing, Cambridge, MA.

Hair, J.F. Jr., Anderson, R.E., Tatham, R.L. and Black, W.C. (1995), Multivariate Data Analysis, Macmillan, New York, NY. 
Haire, M., Ghiselli, E.E. and Porter, L.W. (1963), “Cultural patterns in the role of the manager”, Industrial Relations, Vol. 2 No.1, pp. 95-117.

Harrison G.L., McKinnon J.L., Panchapakesan S. and Leung M. (1994), "The Influence of Culture on Organizational Design and Planning and Control in Australia and the United States Compared with Singapore and Hong Kong”, Journal of International Financial Management and Accounting, Vol. 5 No. 3, pp 242-261.

Hartog, D.N. and Verburg, R.M. (2004), "High performance work systems, organisational culture and firm effectiveness”, Human Resource Management Journal, Vol. 14 No. 1, pp. 55-78.

Hayes, R.H., Weelwrigth, S.C. and Clark, K.B. (1988), Dynamic Manufacturing: Creating the Learning Organization, Free Press, New York, NY.

Hines, P., Holweg, M. and Rich, N. (2004), "Learning to evolve. A review of contemporary lean thinking”, International Journal of Operations \& Production Management, Vol. 24 No. 10, pp. 994-1011.

Hofstede, G. (1980), Culture's consequences: International differences in work related values, Sage, Beverly Hills.

Hofstede, G. (1983), “The cultural relativity of organizational practices and theories”, Journal of International Business Studies, Vol. 14 N. 2, pp. 75-89.

Hofstede, G. (1991), Cultures and organizations, McGraw-Hill, London.

Hofstede, G. (1993), “Cultural dimensions in people management”, in Puick, V., Tichy, N.M. and Barnett C.K. (Eds.), Globalizing Management, Wiley, New York, NY, pp. 139-158.

Hofstede, G.H. and Hofstede, G.J. (2005), Cultures and organizations: software of the mind, McGraw-Hill, New York, NY.

Hult, G., Ketchen Jr D. and Nichols, Jr E. (2003), “Organizational learning as a strategic resource in supply management”, Journal of Operations Management, Vol. 21 No.1, pp. 173-191.

Huselid, M.A. (1995), “The Impact of Human Resource Management Practices on Turnover, Productivity, and Corporate Financial Performance”, Academy of Management Journal, Vol. 38 No. 3, pp. 635-672.

Ichniowski, C. and Shaw, K. (1999), “The Effects of Human Resource Management Systems on Economic Performance: An International Comparison of U.S. and Japanese Plants”, Management Science archive, Vol. 45 No. 5, pp. 704-721.

Ichniowski, C., Shaw, K. and Prennushi, G. (1997), "The Effects of Human Resource Management Practices on Productivity: A Study of Steel Finishing Lines”, The American Economic Review, Vol. 87, No. 3 , pp. 291-313. 
Javidan, M. and House, R. (2001), “Cultural acumen for the global manager: lessons from project GLOBE”, Organizational Dynamics, Vol. 29 No. 4, pp. 289-305.

Kapopoulos, P. and Lazaretou, S. (2009), "Does Corporate Ownership Structure Matter for Economic Growth? A Cross-Country Analysis”, Managerial and Decision Economics, Vol. 30 No.1, pp. 155-172.

Karlsson, C. (1996), “Radically new production system”, International Journal of Operations \& Production Management, Vol. 16, No. 11, pp.8-19.

Karlsson, C. and Åhlström, P. (1995), "Change processes towards lean production: the role of the remuneration system”, International Journal of Operations \& Production Management, Vol. 15, No. 11, pp.80-99.

Ketchen, D.J. Jr. and Shook, C.L. (1996) "The application of cluster analysis in strategic management research: an analysis and critique”, Strategic Management Journal, Vol. 17 No. 1, pp. 441-458.

King, R.G. and Levine, R. (1993), “Finance and Growth: Schumpeter Might be Right”, The Quarterly Journal of Economics, Vol. 108 No. 3, pp. 717-737.

Landsbergis, P.A., Cahill, J. and Schnall, P., (1996), “ New systems of work organization: Impacts on job characteristics and health”, Job Stress Network, Vol.1 No.1, pp. 1-10.

Laurent, A. (1986), “The cross-cultural puzzle of international human resource management”, Human Resource Management, Vol. 25 No.1, pp. 91-102.

Lindberg, P., Voss, C.A. and Blackmon, K. (1998), International Manufacturing Strategies. Context, Content and Change, Kluwer Academic Publishers, Dordrecht.

Luo, X. (2007), "Continuous Learning: The Influence of National Institutional Logics on Training Attitudes”, Organization Science, Vol. 18, No. 2, pp. 280-296.

Luthans, F., Welsh, D.B. and Rosenkrantz, S.A. (1993), "What do Russian managers really do? An observational study with comparisons to U.S. managers”, Journal of International Business Studies, Vol. 24 No. 4, pp. 741-61.

MacDuffie, J.P. (1995), "Human resource bundles and manufacturing performance: organizational logic and flexible production systems in the auto industry”, Industrial and Labor Relations Review, Vol. 48 No. 2, pp. 197-221.

Makino, S., Isobe, T. and Chan, C.M. (2004), “Does country matter?”, Strategic Management Journal, Vol. 25 No.10, pp.1027-1043.

Mellor, R. and Gupta, P. (2002), "Comparing the manufacturing strategies of Australian firms with their European counterparts”, International Journal of Operations \& Production Management, Vol. 22 No. 12, pp. 1411-1428. 
Menard, S. (1995), Applied Logistic Regression Analysis: Sage University Series on Quantitative Applications in the Social Sciences, Sage, Thousand Oaks, CA.

Metters, R, (2008), “A case study of national culture and offshoring services”, International Journal of Operations \& Production Management, Vol. 28 No. 8, pp. 727-747.

Monden, Y. (1983), Toyota Production System, Industrial Engineering and Management Press, Atlanta, GA.

Morden, T. (1999), "Models of National Culture - A Management Review”, Cross Cultural Management, Vol. 6 No. 1, pp. 19-35.

Nakata, C. and Sivakumar, K. (1996), "National Culture and New Product Development: An Integrative Review”, The Journal of Marketing, Vol. 60, No. 1, pp. 61-72.

Neter, J., Wasserman, W. and Kutner, M.H. (1989), Applied Linear Regression Models, Irwin, Homewood, IL.

Newman, K.L. and Nollen, S.D. (1996), “Culture and congruence: The fit between management practices and national culture”, Journal of International Business Studies , Vol. 27 No. 4, pp. 753-779.

Pagell, M., Katz, J.P. and Sheu, C. (2005), “The importance of national culture in operations management research”, International Journal of Operations \& Production Management, Vol. 25 No. 4, pp. 371-394.

Piore, M.J. and Sabel, C.F. (1984), The Second Industrial Divide: Possibilities for Prosperity, Basic Books, New York, NY.

Prahalad, C.K. and Hamel, G. (1996), “Competing in the new economy: Managing out of bounds”, Strategic Management Journal, Vol.17, pp. 237-242.

Radnor, Z.J. and Boaden, R. (2004),“Developing an understanding of corporate anorexia”, International Journal of Operations \& Production Management,Vol. 24 No. 4, pp. 424-440.

Ralston, D.A., Gustafson, D.J., Cheung, F.M. and Terpstra, R.H. (1993), "Differences in Managerial Values - A Study of United States, Hong Kong and PRC Managers”, Journal of International Business Studies, Vol. 24, No. 1, pp. 249-275.

Redding, S. and Venables, A.J. (2004), “Economic geography and international inequality”, Journal of International Economics, Vol. 62 No. 1, pp. 53- 82.

Schneider, S.C. (1989), "Strategy Formulation: The Impact of National Culture, Organization Studies", Organization Studies, Vol. 10 No.2, pp. 149-168.

Schneider, S. C. and Arnoud DeMeyer (1991), “Interpreting and responding to strategic issues: The impact of national culture”, Strategic Management Journal, Vol. 12 No.1, pp. 307-20.

Schonberger, R.J. (1982), Japanese manufacturing techniques-Nine hidden lessons in simplicity, New York: Free Press. Science, Amsterdam. 
Schonberger, R.J. (1986), World Class Manufacturing Techniques. The Lessons of Simplicity Applied, The Free Press, Macmillan, New York, NY.

Schuler, R.S., Dowling, P.J., and De Ceri, H. (1993), “An integrative framework of strategic international human resource management”, International Journal of Human Resource Management, Vol. 4 No. 1, pp. 717-764.

Schwartz, S.H. (1995), “Identifying Culture-Specifics in the Content and Structure of Values”, Journal of Cross-Cultural Psychology, Vol. 26 No. 1, pp. 92-116.

Segal, M.N., Segal, U.A. and Niemczycki, M.A.P. (1993), "Value Network for Cross-National MarketingManagement - A Framework for Analysis and Application”, Journal of Business Research, Vol. 27 No. 1, pp. 65-83.

Sethi, S.P. and Elango, B. (1999), “The influence of "country of origin” on multinational corporation global strategy: A conceptual framework”, Journal of International Management, Vol.5 No. 4, pp. 285-298.

Shah, R. and Ward, P.T. (2003), “Lean manufacturing: context, practice bundles, and performance”, Journal of Operations Management, Vol. 21 No. 1 , pp. 129-149.

Shih, H.A., Chiang, Y.H. and Hsu, C.C. (2006), "Can high performance work systems really lead to better performance?”, International Journal of Manpower, Vol. 27 No. 8, pp. 741-763.

Shingo, S. (1981), Study of Toyota Production System from Industrial Engineering Point of View, Japan Management Association, Tokyo.

Smith, P.B. (1992), “Organizational Behaviour and National Cultures”, British Journal of Management, Vol. 3, No. 1, pp. 39-51.

Smith, V. (1997), “New Forms of Work Organization”, Annual Review of Sociology, Vol. 23, pp. 315-344.

Søndergaard, M. (1994), “Hofstede’s Consequences: A Study of Reviews, Citations and Replications”, Organization Studies, Vol. 15, No. 3, pp. 447-456.

Sousa, R., and Voss, C.A. (2008), “Contingency research in operations management practices”, Journal of Operations Management, Vol. 26 No. 1, pp. 697-713.

Sparrow, P.R. (1995), "Towards a dynamic and comparative model of European human resource management: an extended review”, International Journal of Human Resource Management, Vol. 6 No. 1, pp. 481-505.

Spina, G., Bartezzaghi, E., Bert, A., Cagliano, R., Draaijer, D. and Boer, H., (1996), “Strategically flexible production: the multi-focused manufacturing paradigm”, International Journal of Operations \& Production Management, Vol. 16 No. 11, pp. 20-41. 
Thompson, P. and Wallace, T. (1996), "Redesigning production through teamworking”, International Journal of Operations \& Production Management, Vol. 16 No.2, pp. 103-118.

Trompenaars, F. and Hampden-Turner, C. (1998), Riding the Waves of Culture: Understanding Diversity in Global Business, McGraw-Hill, New York, NY.

van Oudenhoven, J.P. (2001), “Do organizations reflect national cultures? A 10-nation study”, International Journal of Intercultural Relations, Vol. 25 No. 1, pp. 89-107.

Vecchi, A. and Brennan, L. (2009), "A cultural perspective on innovation in international manufacturing”, Research in International Business and Finance, Vol. 23 No. 1, pp. 181-192.

Vitell, S.J., Nwachukwu, S.L. and Barnes J.H. (1993), “The Effects of Culture on Ethical Decision-Making: An Application of Hofstede’s Typology”, Journal of Business Ethic, Vol. 12, No. 10, pp. 753-760.

Voss, C. and Blackmon, K. (1996), "The impact of national and parent company origin on world-class manufacturing. Findings from Britain and Germany”, International Journal of Operations \& Production Management, Vol. 16 No. 11, pp. 98-115.

Voss, C., and Robinson, S. (1987) “Application of just-in-time manufacturing techniques in the United Kingdom”, International Journal of Operations \& Production Management, Vol. 17, No. 4, pp. 46-52.

Way, S.A. (2002), "High Performance Work Systems and Intermediate Indicators of Firm Performance Within the US Small Business Sector”, Journal of Management, Vol.28 No.6, pp. 765-785.

Winch, G., Millar, C. and Clifton, N. (1997), “Culture and Organization: The Case of Transmanche-Link”, British Journal of Management, Vol. 8 No. 3, pp. 237-249.

Womack, J.P., Jones, D.T. and Roos D. (1990), The Machine That Changed the World, Macmillan, New York.

World Bank (2009), World Development Indicators 2009, World Bank, April 2009.

World Economic Forum (2009), The Global Competitiveness Report 2009-2010, World Economic Forum.

Wright, P. M., Gardner, T. M., and Moynihan, L. M. (2003), "The Impact of HR Practices on the Performance of Business Units”, Human Resource Management Journal , Vol. 13 No. 3, pp. 21-36.

Zaheer, S. and Zaheer, A. (1997), “Country effects on information seeking in global electronic networks”, Journal of International Business Studies, Vol. 28 No. 1, pp. 77-100. 